\title{
TINGKAT KESIAPAN (E-READINESS INTERNAL) KELOMPOK TANI PROVINSI JAWA BARAT DALAM MENERAPKAN PENGGUNAAN E-COMMERCETOKO TANI INDONESIA
}

\section{LEVEL OF READINESS (E-READINESS INTERNAL) GROUP OF WEST JAVA PROVINCE IN APPLYING THE USE OF E-COMMERCE TANI INDONESIA STORES}

\author{
Syafira Dwi Soniansi \\ Universitas Padjadjaran \\ E-mail: syafira16001@mail.unpad.ac.id \\ Dr. Iwan Setiawan, SP., MS \\ Universitas Padjadjaran \\ E-mail: iones73@yahoo.com
}

\begin{abstract}
ABSTRAK
Toko Tani Indonesia (TTI) merupakan salah satu e-commerce pertanian yang kini sedang menjadi perhatian di Indonesia yang memberi kemudahan akses pasar bagi Kelompok tani dengan cara menjalin mitra. Dalam prosesnya, ditemukan permasalahan bahwa masih banyak kelompok tani yang tidak melakukan transaksi penjualan salah satunya di provinis Jawa Barat. Penelitian ini bertujuan untuk menentukan tingkat kesiapan (e-readiness) kelompok tani secara internal dalam menerapkan penggunaan e-Commerce TTI. Metode yang digunakan adalah metode kuantitatif dengan teknik pengumpulan data survei dan teknik penentuan responden simple random sampling. Sampel penelitian adalah 34 kelompok tani yang berada di provinsi Jawa Barat dan terjalin mitra dengan TTI. Hasil penelitian ini menunjukan bahwa tingkat kesiapan kelompok tani terhadap penggunaan e-commerce pada aspek Awareness, governance, komitmen, sumber daya bisnis, dan sumber daya teknologi sudah siap sedangkan pada aspek sumber daya manusia dalam kategori cukup. Hal tersebut karena kelompok tani terkendala dengan masalah pengetahuan dan terbatasnya individu yang ahli. Faktor awareness adalah faktor yang paling mempengaruhi tingkat kesiapan kelompok tani. Diharapkan terutama bagi ketua kelompok tani , agar dapat lebih mendorong anggota kelompok taninya untuk menjadi kelompok tani berbasis teknologi.
\end{abstract}

Kata Kunci: E-Readiness Internal, E-Commerce, kelompok tani, Toko Tani Indonesia

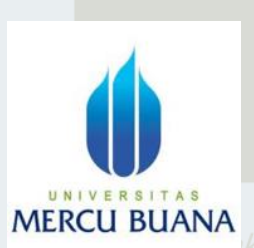

Jurnal Perilaku Dan Strategi Bisnis

Vol.8 No. 1, 2020

Hal. $17-26$

\section{ABSTRACT}

Toko Tani Indonesia (TTI) is one of the agricultural e-commerce that is now a concern in Indonesia that provides the ease of access to markets for the farmer group by establishing partners. In the process, there is a problem that there are still many farmer groups that do not conduct sales transactions one of them in the province of West Java. This research aims 
to determine the level of readiness (e-readiness) of the Farmer group internally in implementing the use of E-Commerce TTI. The methods used are quantitative methods with survey data collection techniques and simple random sampling respondent determination techniques. The research samples are 34 farmer groups located in West Java province and tied partners with TTI. The results of this research show that the level of readiness of farmers to use e-commerce on the aspect of Awareness, governance, commitment, business resources, and technology resources is ready while on the human resources aspect in the category Enough. This is because the farmer group is constrained by the knowledge and limited individuals who are skilled. The awareness factor is the most affecting farmer's level of readiness. It is hoped especially for the leader of the farmer group, in order to further encourage members of the land group to become a technology based farmer group.

\section{Keywords: E-Readiness Internal, E-Commerce, farmers groups, Toko Tani Indonesia}

\section{PENDAHULUAN}

Indonesia merupakan negara agraris. Dalam hasil survei Badan Pusat Statistik (BPS) terkait pertumbuhan ekonomi pada Triwulan III 2018 yang menyatakan kontribusi pertanian terhadap laju pertumbuhan produk domestik bruto (PDB) mencapai 13,53\%. Fakta ini menunjukkan bahwa sektor pertanian merupakan salah satu pendorong utama dalam pembangunan ekonomi masyarakat Indonesia. Oleh karena itu sektor pertanian perlu didukung dalam pengembangannya, sehingga sektor ini memiliki peluang yang lebih besar.

Sektor pertanian memiliki peluang yang besar untuk berkembang dalam memenuhi kebutuhan hidup manusia, sehingga dibutuhkan penyesuaian yang tepat seiring berkembangnya zaman terutama dalam hal teknologi. Saat ini dunia telah memasuki era Revolusi industri 4.0. Istilah industri 4.0 secara resmi pertama kali dipresentasikan di Hannover Fair Jerman pada tahun 2012 sebagai satu dari sepuluh "Proyek masa depan" yang dibuat oleh Germany's High-Tech Strategy 2020 (Kinzel, 2016). Singkatnya, gagasan revolusi industri 4.0 adalah tren di dunia industri yang menggabungkan teknologi otomasi dengan teknologi cyber. Perkembangan indutri 4.0 ini sangat pesat, salah satu dampaknya adalah pertumbuhan pengguna internet di dunia meningkat terutama di Indonesia. Jumlah pengguna internet pada tahun 2017 telah mencapai 143,26 juta orang, hal ini setara dengan 54,68 persen dari total populasi Indonesia.

Salah satu perkembangan dalam teknologi komunikasi dan informasi yang dihasilkan dari adanya peningkatan penggunaan internet adalah munculnya e-Commerce. eCommerce adalah seperangkat teknologi yang dinamis, aplikasi, dan proses bisnis yang menghubungkan perusahaan, konsumen, dan komunitas tertentu melalui transaksi elektronik dan perdagangan barang, pelayanan, dan informasi yang dilakukan secara elektronik (Yulimar, 2010). Pada tahun 2018, e-Commerce di Indonesia mengalami pertumbuhan yang sangat cepat. Menurut Sensus data Badan Pusat Statistik (BPS) menyebutkan bahwa industri e-Commerce Indonesia dalam 10 tahun terakhir telah mengalami peningkatan sebesar $17 \%$ dan Indonesia menjadi pasar terbesar e-commerce di Asia Tenggara. Menurut data Euromonitor (2014), penjualan online Indonesia mencapai US\$ 1,1 miliar atau lebih tinggi dibanding Thailand dan Singapura. Artinya, pasar e-commerce Indonesia berpeluang untuk tumbuh semakin besar. Apalagi dengan modal jumlah penduduk dan produk domestik bruto (PDB) terbesar di antara negara-negara ASEAN.

Dampak e-Commerce ini telah memberi pengaruh ke semua bidang kehidupan manusia termasuk ekonomi dan pertanian. Salah satu e-Commerce pertanian yang sedang menjadi perhatian adalah e-Commerce Toko Tani Indonesia (TTI) yang merupakan pengembangan dari program PUPM oleh Kementrian Pertanian. Kementrian Pertanian Indonesia mengimplementasikan platform B2B e-Commerce yang digunakan oleh kelompok tani penghasil beras serta TTIC. Program ini telah dilaksanakan sejak tahun 2015 dengan diresmikan oleh Menteri Pertanian Indonesia Bapak Dr. Ir. H. Andi Amran Sulaiman, MP. 
Tujuan utama dari program TTI adalah memotong rantai pasok sistem agribisnis Indonesia sehingga memberikan tingkat keuntungan yang seimbang antara keuntungan harga yang diterima petani dan keuntungan yang didapat konsumen dari harga produk yang lebih murah.

Berdasarkan data dari Kementrian Pertanian, pada tahun 2018 terdapat 2.443 Toko Tani Indonesia Center (TTIC) yang berdiri dan tersebar di 32 provinsi di Indonesia dan jumlah pengunduh aplikasi TTI telah mencapai 1.173 terdiri dari pihak Kelompok Tani, Pendamping serta pemilik TTIC. Saat ini, sudah ada 898 Kelompok Tani yang bergabung dan 52 diantaranya berasal dari kelompok tani di Jawa Barat. Berdasarkan data sistem informasi TTI, provinsi Jawa Barat merupakan salah satu provinisi yang memiliki penjulan terbesar. Untuk paruh pertama tahun 2019 penjualan provinsi jawa barat tercatat menjadi penjualan terbesar ke-4 yakni telah melebihi 500 ton. Dengan bergabunganya kelompok tani provinsi Jawa Barat dengan e-commerce TTI tersebut, diharapkan penjualannya dapat meningkat dan produknya dipasarkan secara lebih luas.

Akan tetapi dalam proses pengembangan e-Commerce TTI, Inti Pertiwi Nasywari selaku Manajer TTI sekaligus Kepala Bidang Distribusi Pangan, Badan Ketahanan Pangan, Kementrian Pertanian mengukapkan meski e-Commerce TTI mudah diaplikasikan, namun tidak semua kelompok tani dan pengelola TTI melakukan transaksi, diantaranya akibat terbatasnya kemampuan dalam menggunakannya.Banyaknya kelompok tani sudah bersedia untuk menjalin mitra dengan TTI khususnya yang ada di Jawa Barat, akan tetapi belum diketahui apakah mereka siap untuk menggunakannya secara langsung dalam sistem pemasaran produk pertanian. Untuk mengetahui bagaimana tingkat kesiapannya dapat diukur melalui faktor internal kelompok tani tersebut yaitu tingkat kesadaran (awareness), tata kelola (governance), komitmen, sumber daya bisnis, sumber daya manusia dan sumber daya teknologi.

\section{METODE PENELITIAN}

Penelitian ini dilakukan dengan metode kuantitaf dan teknik penelitian survey, untuk mengidentifikasi masalah menggunakan teknik statistik dan ilmiah berdasarkan data yang telah dijawab oleh responden yang bertindak sebagai sampel.

Penelitian ini berfokus pada Tingkat kesiapan (E-readiness Internal) kelompok tani provinsi Jawa Barat dalam menerapkan penggunaan e-Commerce toko tani indonesia. Lokasi penelitian dipilih secara purposive dengan mempertimbangkan bahwa wilayah provinsi Jawa Barat memiliki hasil penjualan terbesar pada e-Commerce tersebut tersebut selain itu wilayah tersebut sudah dilengkapi dengan fasilitas internet yang memadai di beberapa daerah.

Teknik yang digunakan untuk melakukan pengambilan sampel adalah simple random sampling. Untuk penentuan jumlah sampel atau kelompok tani responden dapat digunakan rumus yang dikemukakan oleh Slovin dalam Umar (2003). Jumlah sampel yang diambil sebanyak 34 ketua kelompok tani yang sedang bermitra dengan e-Commerce Toko Tani Indonesia dari total populasi yakni 52 kelompok tani.

Penelitian ini menggunakan model Perceived Organizational E-Readiness factors (POER) yang dikembangkan oleh Molla dan Licker (2005) atau bisa disebut e-readiness internal. Pengukuran tingkat kesiapan dengan model e-readiness Internal menggunakan variabel berikut :

1. Awareness (Kesadaran) diukur melalui pemahaman yang tajam tentang struktur pelayanan, teknologi, persyaratan, manfaat dan ancaman sebagai serta perkiraan tren masa depan dan dampaknya.

2. Governance (tata kelola) merupakan suatu institusi sebagai model taktis dan strategis organisasi dimasukkan untuk memantau kegiatan mereka dan inisiatif e-commerce.

3. Komitmen menjelaskan dukungan strategis dan organisasi terhadap bisnis elektronik. Selain itu, komitmen mengacu pada kemilikan visi organsasi yang jelas dan mengacu 
pada bagaimana kehendak anggota dalam menerima dan mendukung gagasan ecommerce.

4. Sumber daya bisnis menjelaskan kemampuan aset berwujud dari suatu organisasi. Sumber daya bisnis termasuk komunikasi, keterbukaan, hubungan yang ada, pendanaan proyek pengadaan elektronik dan perilaku pengambilan risiko.

5. Sumber daya manusia menjelaskan ketersediaan sumber daya manusia dan anggota dalam keterampilan dan pengetahuan IT untuk menjalankan penggunan e-commerce.

6. Sumber daya teknolgi menjelaskan mekanisme dan sarana yang dimiliki dalam mengakses e-commerce. Bagaimana tingkat komputerisasi dan fleksibilitasnya sistem saat diterapkan, dan pengalaman organisasi dalam sistem internet.

7. Penggunan e-Commerce

Pada penelitian ini skala likert digunakan untuk menentukan skor pada jawaban yang diberikan oleh kelompok tani .Kriteria skor yang diberikan adalah (sangat setuju :5), (Setuju :4), (Cukup :3), (Tidak Setuju :2) dan (Sangat tidak setuju :1).

\section{HASIL DAN PEMBAHASAN Karakteristik Kelompok Tani Usia}

Berdasarkan hasil penelitian, dapat diketahui bahwa mayoritas responden berusia 41-50 tahun yakni sebanyak 13 responden (41\%), kemudian diikuti dengan responden berusia 31-40 tahun sebanyak 10 responden (31\%), usia 51-60 tahun sebanyak 7 responden (22\%), dan usia 21-30 tahun dan 61-70 tahun masing- masing sebanyak 2 responden (6\%). Seperti dijelaskan pada gambar 1.

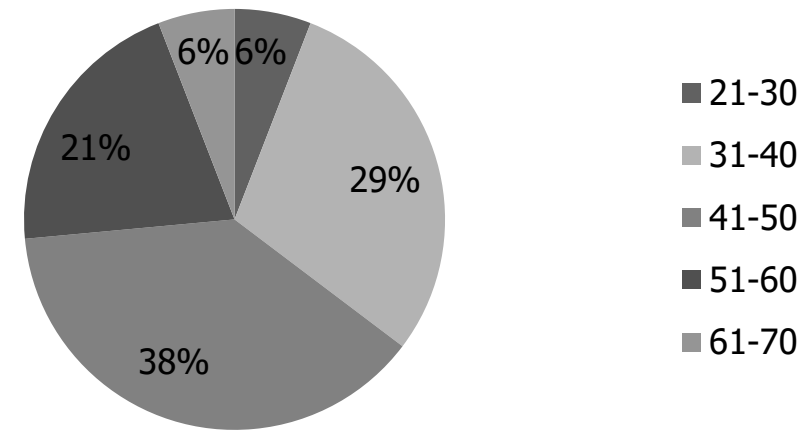

Gambar 1. Diagram ketua kelompok tani berdasarkan usia

Berdasarkan hasil tersebut, penulis mengobservasi tentang rentang usia petani yang siap menerima penggunaan e-Commerce ini yaitu usia petani umur 30-50 tahun memiliki fisik yang potensial untuk mendukung kegiatan usahatani, dinamis, kreatif, dan cepat dalam menerima inovasi teknologi baru (Samun et al., 2011).

\section{Domisili Kelompok Tani}

Berdasarkan hasil penelitian, dapat diketahui bahwa responden terbanyak berasal dari daerah Kabupaten Bandung, Kabupaten Bogor, Kabupaten Cianjur, Kabupaten Cirebon, kabupaten Sukabumi dan Kabupaten Sumedang yang masing-masing sebanyak 3 kelompok tani $(8,8 \%)$, kemudian diikuti responden berasal dari daerah Kabupaten Ciamis, Kabupaten Garut, Kabupaten Indramyu, Kabupaten Karawang, Kota Sukabumi dan Kabupaten Tasikmalaya yang masing-masing sebanyak 2 kelompok tani $(5,8 \%)$ dan domisili lainnya hanya mendapat 1 kelompok tani $(2,9 \%)$. Berikut penjelasannya terdapat di tabel 2 .

Tabel 2. Presentase distribusi domisili kelompok tani

\begin{tabular}{lcc}
\hline Domisili Kelompok tani & Jumlah Responden & Presentase \\
\hline Kab. Bandung & 3 & 8,8 \\
Kab. Bogor & 3 & 8,8 \\
Kab. Ciamis & 2 & 5,8
\end{tabular}




\begin{tabular}{llc} 
Kab. Cianjur & 3 & 8,8 \\
Kab. Cirebon & 3 & 8,8 \\
Kota Cirebon & 1 & 2,9 \\
Kab. Garut & 2 & 5,8 \\
Kab. Indramayu & 2 & 5,8 \\
Kab. Karawang & 2 & 5,8 \\
Kab. Kuningan & 1 & 2,9 \\
Kab. Subang & 1 & 2,9 \\
Kab. Sukabumi & 3 & 8,8 \\
Kota Sukabumi & 2 & 5,8 \\
Kab. Sumedang & 3 & 8,8 \\
Kab. Tasikamalaya & 2 & 5,8 \\
Kota Tasikmalaya & 1 & 2,9 \\
\hline Jumlah & 34 & $100 \%$ \\
\hline
\end{tabular}

\section{Tingkat Pendidikan}

Berdasarkan hasil penelitian, dapat diketahui bahwa mayoritas responden memiliki latar belakang pendidikan yakni SMA sebanyak 18 orang (53\%), kemudian diikuti dengan responden memiliki latar belakang pendidikan yakni SMP sebanyak 10 orang $(29 \%)$, responden memiliki latar belakang pendidikan yakni lainnya (S1,D3,D4) sebanyak 4 orang $(12 \%)$ dan responden memiliki latar belakang pendidikan yakni SD sebanyak 2 orang (6\%). Seperti dijelaskan pada gambar 2 .

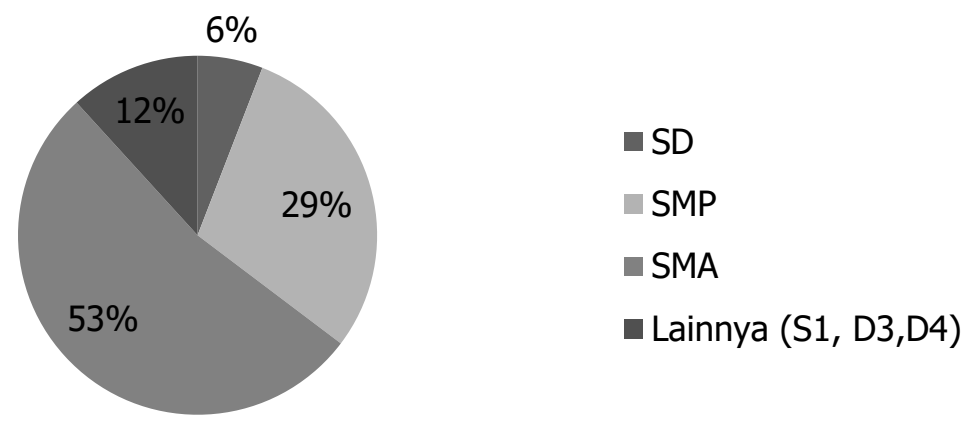

Gambar 2. Diagram ketua kelompok tani berdasarkan tingkat pendidikan

Berdasarkan hasil tersebut, penulis mengobservasi bahwa semakin tinggi tingkat pendidikan seseorang maka akan semakin mudah indivisu tersebut menerima teknologi. Mardikanto (1993) mengatakan bahwa kapasitas dan kecepatan adopsi dipengaruhi oleh tingkat pendidikan terutama untuk jenis teknologi yang membutuhkan pemahaman lebih tinggi.

\section{Jumlah Anggota yang Memahami Internet}

Berdasarkan hasil penelitian yang dijelaskan pada gambar 3, dapat diketahui bahwa mayoritas responden berasal dari kelompok tani dengan jumlah anggota yang memahami internet sebanyak 3-5 orang yakni 11 kelompok tani (32\%), kemudian diikuti dengan kelompok tani dengan jumlah anggota yang memahami internet sebanyak 6-8 orang yakni 9 kelompok tani (26\%), kelompok tani dengan jumlah anggota yang memahami internet sebanyak $>8$ orang yakni 8 kelompok tani (24\%) dan kelompok tani dengan jumlah anggota yang memahami internet sebanyak 0-2 orang yakni 6 kelompok tani $(18 \%)$. 


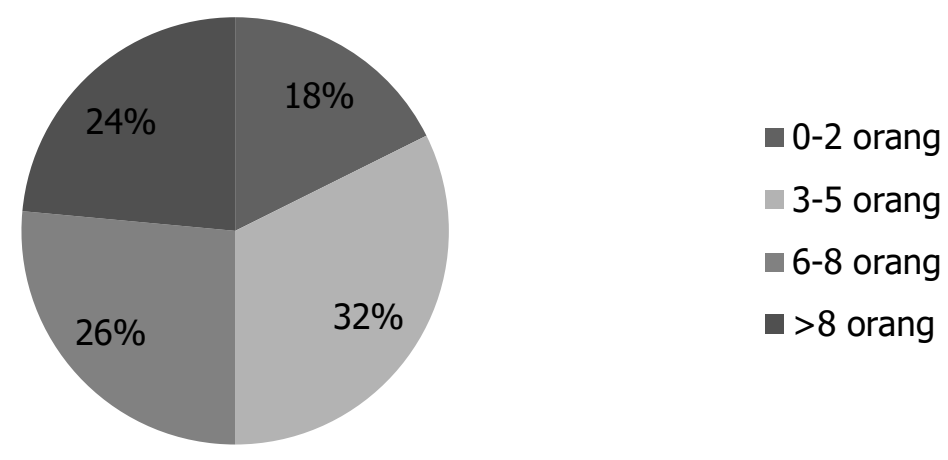

Gambar 3. Diagram jumlah anggota yang memahami internet

Inovasi pertanian yang memadai dan tepat waktu didukung informasi pertanian dapat digunakan sebagai dasar strategi penguasaan pasar dan dasar perencanaan untuk pengembangan usaha tani lebih lanjut (Mulyandari,2005) Berdasarkan hal tersebut, penulis mengobservasi bahwa jika semakin banyak anggota yang memahami internet maka kelompok tani tersebut akan semakin mudah untuk menguasai pasar .

\section{Peluang dalam Memanfaatkan e-Commerce}

Berdasarkan hasil penelitian, dapat diketahui bahwa mayoritas responden merasa pemanfaatan e-Commerce menjanjikan sebanyak 20 kelompok tani $(59 \%)$, kemudian diikuti dengan pemanfaatan e-Commerce sangat menjanjikan sebanyak 14 kelompok tani (41\%), dan tidak ada yang memilih pemanfaatan e-Commerce kurang menjanjikan dan tidak menjanjikan. Seperti dijelaskan pada gambar 4.

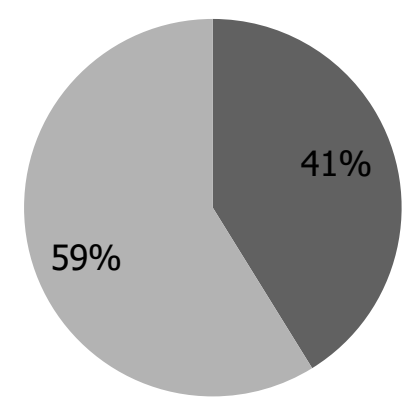

- Sangat Menjanjikan

Menjanjikan

Gambar 4. Diagram peluang dalam memanfaatkan e-commerce

Manfaat dari pengggunan e-Commerce yang dapat dirasakan oleh petani adalah semakin luasnya jalur pemasaran yang akan meninggkatkan permintaan produksi dan memacu pengadaan produksi pertanian yang secara tidak langsung akan meningkatkan taraf hidup para petani (Swandayani,2014) Berdasarkan hal tersebut, penulis mengobservasi bahwa petani merasakan akan peluang dari pemanfaat e-Commerce tersebut.

\section{Kendala dalam memanfaatkan e-Commerce}

Berdasarkan hasil penelitian, dapat diketahui bahwa mayoritas responden merasa kendala dalam memanfaatkan penggunaan e-Commerce adalah kuranganya pengetahuan sebanyak 25 kelompok tani $(73 \%)$, kemudian diikuti infrastuktur tidak memadai sebanyak 6 kelompok tani $(18 \%)$, anggota yang tidak siap sebanyak 2 kelompok tani (6\%) dan faktor lingkungan setempat sebanyak 1 kelompok tani (3\%). Seperti dijelaskan pada gambar 5. 


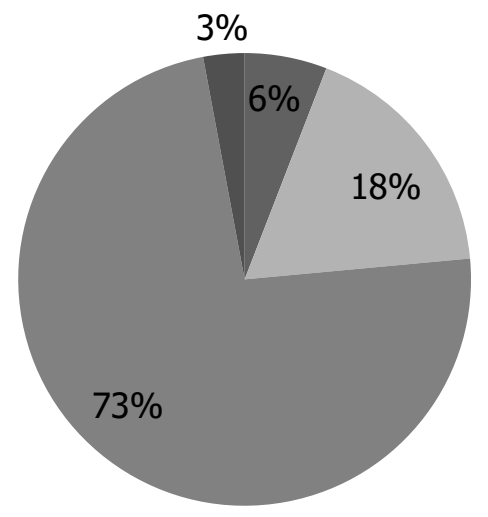

- Anggota yang tidak siap

Infrastuktur tidak memadai

Kurangnya pengetahuan

- Lingkungan setempat

Gambar 5. Diagram kendala dalam memanfaatkan e-commerce

\section{Analisis Deskripsi Tingkat Kesiapan}

Pada bagian berikut akan membahas analisis penelitian tentang penggunaan $e-$ commerce toko tani indonesia oleh kelompok tani di Provinsi Jawa Barat melalui kesiapan secara internal. Selanjutnya akan diberikan penjelasan berdasarkan tiap tiap variabel sebagai berikut:

\section{Awareness}

Berdasarkan hasil penelitian, diketahui bahwa untuk indikator Awareness, rata - rata kelompok tani memiliki kecenderungan jawaban adalah antara cukup dan setuju, hal ini terlihat dari rata - rata frekuensi atas jawaban ini yaitu sebesar 11,2 dan 17,5. Pernyataan dengan rata - rata skor terendah yaitu sebesar 3,23 terletak pada pengetahuan model organisasi yang cocok untuk menjalankan usaha menggunakan internet (X1.6). Hal ini berarti mayoritas kelompok tani tidak mengerti atau tidak mengetahui bagaimana model organisasi yang cocok untuk diterapkan dalam melakukan bisnis dengan media e-commerce. Sedangkan peryataan yang mendapat respon positif dari kelompok tani adalah keinginan untuk menjalakan usaha secara elektronik dan menggunakan internet (X1.1 dan X1.2). Usaha secara elektronik diartikan sebagai kegiatan bisnis yang dilakukan secara otomatis dengan menggunakan sistem informasi komputer. Sedangkan usaha menggunakan internet dapat diartikan sebagai bisnis online.

Perolehan untuk rata - rata variabel ini adalah 3,55 yang menyatakan bahwa tingkat kesadaran (Awareness) kelompok tani dinilai siap dalam menerapkan penggunaan $e$ commerce Toko Tani Indonesia $(>3,00)$. Kelompok tani dapat dinyatakan siap karena mereka memiliki keinginan serta berusaha menjadi kelompok tani yang ideal bagi bisnis $e-$ commerce. Hal ini sama dengan hasil dari penilitian Taryadi (2016), bahwa variabel tingkat kesadaran UMKM dinilai siap dalam mengadopsi e-marketplace.

\section{Governance}

Respon yang hampir sama juga ditunjukkan pada indikator Governance. Rata - rata kelompok tani menjawab dari rentang cukup setuju dan setuju untuk pernyataan pernyataan pada indikator ini. Pada hasil penelitian, rata - rata frekuensi masing - masing adalah sebanyak 11,5 dan 15,1 . Pernyataan dengan rata - rata skor terendah yaitu terletak pada dukungan seluruh anggota terhadap penggunan e-Commerce (X2.7). Hal ini mengartikan bahwa anggota dalam mayoritas kelompok tani kurang menyetujui adanya kemitraan dengan e-commerce tersebut. Bagi para anggota, e-commerce dianggap rumit dan hanya menguntungkan beberapa pihak. Sedangkan pernyataan yang mendapat skor terbesar dari kelompok tani adalah peran organisasi terhadap penggunaan e-commerce dan kewenangan pengambilan keputusan (X2.1 dan X2.3). Hal ini menunjukan bahwa mayoritas 
kelompok tani berfikir bahwa peran organisasi dan pengambilan keputusan harus tepat dan sesuai. Dapat dikatakan tepat apabila tidak ada penyalahgunaan kekuasaan.

Berdasarkan hasil penelitian, Perolehan untuk rata - rata variabel ini adalah 3,52 yang menyatakan Tata Kelola (Governance) kelompok tani dinilai siap dalam menerapkan penggunaan e-Commerce $(>3,00)$. Kelompok tani dapat dinyatakan siap karena kelompok tani mempunyai model taktis dan strategis untuk memantau kegiatan bisnis mereka.

\section{Komitmen}

Berdasarkan hasil penelitian diperoleh bahwa mayoritas kelompok tani menjawab dari rentang cukup setuju hingga setuju, dengan rata -rata frekuensi jawaban masing - masing sebesar 28 dan 23.67. Pernyataan dengan rata - rata skor terendah terletak pada pencapaian tehadap insiatif menjalankan usaha menggunakan internet (X3.8). Hal ini berarti pada awalnya mayoritas kelompok tani tidak pernah mengambil langkah untuk menjalankan usaha dengan menggunakan internet. Sedangkan peryataan yang mendapat skor terbesar dari kelompok tani adalah visi/misi organisasi dalam menjalankan usaha secara elektronik (X3.1). Hal ini menunjukan bahwa mayoritas kelompok tani merasa bahwa visi/misi organisasi sangat penting karena dapat menentukan apa saja langkah yang tepat yang sesuai dengan tujuan awal.

Berdasarkan hasil penelitian, Perolehan untuk rata - rata variabel ini adalah 3,18 yang menyatakan Komitmen kelompok tani dinilai siap dalam menerapkan penggunaan $e-$ commerce $(>3,00)$. Kelompok tani dinilai siap karena dari landasan yang dimiliki organisasi seperti visi dan misi sudah diimplementasikan dengan kuat.

\section{Sumber Daya Bisnis}

Berdasarkan hasil penelitian, memperlihatkan bahwa mayoritas kelompok tani menjawab dari rentang cukup setuju hingga sangat setuju. Hal ini berarti persepsi kelompok tani lebih positif untuk indikator ini.Pernyataan dengan rata - rata skor terendah yaitu terletak pada kegagalan dapat ditolerir oleh organisasi (X4.6). Hal ini berarti mayoritas kelompok tani merasa bahwa tidak dapat menanggung dampak dari adanya kegagalan dan berusaha untuk menghindarinya.. Sedangkan peryataan yang mendapat skor terbesar dari kelompok tani adalah keterbukaan organisasi terhadap informasi (X4.3). Hal ini berarti mayoritas kelompok tani mengatakan bahwa kelompok tani yang mereka kelola memang memiliki kebudayaan atau kebiasaan untuk berbagi informasi.

Berdasarkan hasil penelitian, Perolehan untuk rata - rata variabel ini adalah 3,72 yang menyatakan sumber daya bisnis kelompok tani dinilai siap dalam menerapkan penggunaan e-Commerce Toko Tani Indonesia $(>3,00)$. Kelompok tani dinilai siap karena memiliki kemampuan aset termasuk komunikasi, keterbukaan, hubungan yang ada serta perilaku pengambilan risiko. Hal ini sama dengan hasil dari penilitian Era yunianto, dkk. (2015), bahwa variabel sumber daya bisnis UMKM batik dikota Pekalongan dinilai siap dalam mengadopsi e-marketplace.

\section{Sumber Daya Manusia}

Pernyataan yang mewakili indikator sumber daya manusia memiliki respon yang berimbang. Hal ini terlihat dari penyebaran jawaban yang merata dari kelompok tani atas dua pernyataan yang menerangkan indikator sumber daya tersebut. Berdasarkan hasil penelitian , Perolehan untuk rata - rata variabel ini adalah 2,73 yang menyatakan sumber daya manusia kelompok tani hanya dinilai cukup dalam menerapkan penggunaan $e$ Commerce $(<3,00)$.

Dua pernyataan ini memiliki persepsi yang berbeda. Pernyataan satu bersifat positif sedangkan pernyataan dua negatif. Jadi berdasarkan rata - rata jawaban kelompok tani diperoleh kesimpulan mayoritas kelompok tani anggotanya tidak memiliki pengetahuan yang cukup terkait teknologi dan mengalami keterbatasan dalam menggunakannya. 


\section{Sumber Daya Teknologi}

Berdasarkan hasil penelitian dijelaskan bahwa rata - rata jawaban kelompok tani hanya menjawab cukup setuju. Meski yang menjawab setuju mayoritas, namun tidak sebesar yang menjawab cukup setuju. Nilai rata - rata tertinggi adalah yang menjawab cukup setuju yaitu sebesar 13,8 . Pernyataan dengan rata - rata skor terendah yaitu terletak pada pengalaman dalam menggunakan internet (X6.1). Hal ini berarti mayoritas kelompok tani tidak memiliki pengalaman cukup dalam menggunakan internet. Sedangkan peryataan yang mendapat skor tertinggi dari kelompok tani adalah kemampuan dalam menghadapi perubahan lingkungan (X6.2). Hal ini menunjukan bahwa mayoritas kelompok tani merasa cukup mampu dalam menghadapi perubahan aktivitas bisnis dari konvensional menjadi lebih canggih yakni menggunakan sistem internet.

Berdasarkan hasil penelitian , Perolehan untuk rata - rata variabel ini adalah 3,01 yang menyatakan sumber daya teknologi kelompok tani dinilai siap dalam menerapkan penggunaan e-Commerce $(>3,00)$. Kelompok tani dinilai siap karena walaupun pengalaman menggunnakan internet mereka masih rendah tapi mereka mampu menghadapi perubahan lingkungan, salah satunya berusaha menerapkan teknologi baru yakni media e-commerce.

\section{Penggunaan e-Commerce}

Berdasarkan data hasil analisis penelitian terhadap variabel $Y$ yakni penggunaan $e$ Commerce dapat disimpulkan bahwa mayoritas kelompok tani menyatakan cukup siap hingga sangat siap dalam menggunakan e-Commerce.Berdasarkan hasil data memperlihatkan persepsi kelompok tani atas pernyataan- pernyataan yang menerangkan indikator penggunan e-Commerce. Hal Ini terlihat dari adanya sebanyak 20 kelomppk tani yang menyatakan siap dengan menggunakan e-commerce. Sedangkan sebaliknya, ada sebesar 1 kelompok tani yang menyatakan tidak siap dalam menjalankan kelompok tani dengan menggunakan internet dan elektronik.

Berdasarkan data hasil analisis penelitian terhadap variabel $Y$ yakni penggunaan $e-$ Commerce dapat disimpulkan bahwa mayoritas kelompok tani sudah memasuki tahap siap karena mereka menjawab dari rentang cukup hingga sangat setuju dalam menggunakan $e$ Commerce.

\section{KESIMPULAN}

Tingkat kesiapan (e-readiness interna) kelompok tani di provinsi Jawa Barat mitra TTI sudah memiliki tingkat kesiapan yang baik untuk variabel kesadaran, tata kelola, komitmen, sumber daya bisnis, dan sumber daya teknologi $(>3,00)$. Sementara itu, tingkat kesiapan berdasarkan variabel sumber daya manusia dalam kategori kesiapan yang cukup $(<3,00)$.

Diharapkan terutama bagi ketua kelompok tani, agar dapat mendorong anggota kelompok taninya untuk menjadi kelompok tani berbasis teknologi sehingga akan lebih efisien dan efektif dan mampu mendukung pasar yang tidak terbatas. Sebagian besar kelompok tani sepenuhnya memahami potensi yang diperoleh dari penggunaan eCommerce, tetapi mereka terkendala oleh masalah pengetahuan dan terbatasnya jumlah individu yang terampil ini. Hal ini serupa dengan hasil jawaban responden terkait kendala penggunaan terhadap e-Commerce.

\section{DAFTAR PUSTAKA}

Kalakota, R. and Whinston, A, B. 1997. Electronic Commerce: a manager's guide,Addison-Wesley: Reading, Mass: Harlow, England.

Kinzel, H. (2016). Industry 4.0 -Where Does This Leave The Human Factor?

Lai., Jung-Yu \& Ong. Chorng-Shyong, 2010, Assessing and managing employees for 
embrasing change: $A$ multiple-item scale to measure employee readiness for $e$ business, Technovation, Vol 30, pp. 76-85.

Mardikanto, T. 1993. Penyuluhan Pembangunan Pertanian. Sebelas Maret University Press. Jakarta.

McLeod, Raymond, Jr \& schell, George P, 2008, Sistem Informasi Manajemen, Edisi 10, Terjemahan oleh Ali Akbar Yulianto dan Afia R. Fitriati, Salemba Empat, Jakarta

Mengakses www.Bps.go.id pada tanggal 18 juni 2019

Mengakses http://tti.pertanian.go.id pada tanggal 9 September 2019

Molla, A. dan Licker, P. (2005), Perceived E - Readiness Factors in E -Commerce Adoption: An Empirical Investigation in a Developing Country, International Journal Of Electronic Commerce, 10, 1, $83-110$.

Mulyandari, R.S., Sumardjo, panjaitan, N.K., Lubis, D.P. 2005. Implementasi Cyber Extension dalam komunikasi Inovasi Pertanian. Informatika Pertanian Volume 19, No.2, IPB

Samun S., Rukmana D. \& Syam S. 2011. Partisipasi petani dalam penerapan teknologi pertanian organik pada tanaman stroberi di Kabupaten Bantaeng. hal.1-12.

Taryadi. 2016. Pengukuran Tingkat Kesiapan Adopsi E-Marketplace Bagi Umkm Batik Dengan Model E-Readiness. Yogyakarta

Turban E., King D., Lee J., Warkentin M and Chung H.M. 2002.Electronic Commerce 2002 A Managerial Perspective (Second Edition). New York:Pretince Hall.

Yulimar, V. A. (2008). Analisis Faktor-Faktor Yang Mempegaruhi Pengadopsian Electronic Commerce Dan Pengaruhnya Terhadap Kinerja Perusahaan (Studi Pada Perusahaan Kecil dan Menengah Di Indonesia). In Seminar Nasional Aplikasi Sains dan Teknologi 2008 (pp. 118-128). 